\title{
Bank Stability and Competition: Evidence from Albanian Banking Market
}

\author{
Gerti SHIJAKU*
}

\begin{abstract}
This paper analyses the inter-temporal competition - stability nexus after the global financial crises. For this reason, the empirical estimation approach follows a five step procedure. First, we utilise quarterly macroeconomic and balance sheet and income statement data for 16 banks operating in the Albanian banking sector over the period 2008 - 2015. Second, we calculate a new composite index as a measure of bank stability conditions, which includes a wide set of information rather than focusing only on one aspect of risk. Then, we construct a proxy for bank competition such as the Boone indicator. Empirical estimations are based on the General Method of Moments approach. A set of robustness checks include also the use of other alternative proxy of competition such as the Lerner index and the efficientadjusted Lerner index, profit elasticity and the Herfindahl index. Empirical results strongly support the "competition - stability" view after the global financial crises that higher degree of competition boosts further bank stability conditions. Results further indicate that greater concentration has also a negative impact on bank stability. Results imply also that bank stability is positively linked with macroeconomic conditions and capital ratio and inverse with operational efficiency. Finally, we do not find a non-linear relationship between competition and stability.
\end{abstract}

Keywords: Bank stability, Competition, Boone indicator, Panel Data, GMM.

JEL Code Classification: C26, E32, E43, G21, H63.

UDC: 336.71(496.5)

DOI: https://doi.org/10.17015/ejbe.2017.019.07

\footnotetext{
Research Department, Bank of Albania, Tirana, Albania. Email: gshijaku@bankofalbania.org, shijakugerti@gmail.com
} 


\section{Introduction}

The international process of banking liberalisation, triggered by excessive bank risk taking, has gone hand in hand with an increased occurrence of systemic banking crises, culminating during the Global Financial Crises (henceforth GFC) of 20072009 (Beck, De Jonghe, \& Schepens, 2013). This has yet again heightened interest on how bank stability is affected by market structure developments in particular those related the degree of bank competition. However, there is not yet a scientific consensus on whether bank competition mitigates or exacerbates bank stability as the predications emerging from the theoretical models and empirical studies are ambiguous and so far are also inconclusive (Kasman \& Carvallo, 2014). The traditional view argues that fiercer competition among banks would give them proper incentives to obey the rules prudently and therefore lead to a more efficiency banking system, which benefits bank stability (Boyd \& De Nicolo 2005, Beck, Demirgüç-Kunt, \& Levine, 2006; Schaeck et al. 2009; Schaeck \& Cihak, 2014). However, others have challenged this view, instead arguing that higher competition among banks reduces market power and profit margins, which essentially lowers the franchise value of banks. As a result, this will encourage banks to take greater risks so as to make up the loss of declined profit (franchise value), which may also lead them to take on more risky investment approach and eventually increase the possibility of a bank crisis (Keeley, 1990; Allen \& Gale, 2004; Boyd et al., 2006; Agoraki, Delis \& Pasiouras, 2011; Leroy \& Lucotte, 2017).

This similarly inconclusive debate is particularly critical for Albania, where the financial system consists mainly of the operation of the banking sector and a large number of banks operate in a specific small opened economy, and equity market is remarkably underdeveloped. For example, by the end of 2015 , the ratio of financial system assets to GDP reached $99.2 \%$, with the banking sector owning $91.4 \%$ of financial system assets ( $90.6 \%$ of GDP), while stock market capitalization is the lowest in South - Eastern Europe (SEE). On the one hand, the financial developments of the banking sector has been the main driving force behind economic prospect, while improving market and macroeconomic conditions, as well as increasing competition have motivated larger foreign banks in more developed countries, mostly in the Eurozone, operating at relatively lower margins to extend cross-border operations into potentially new and more profitable market such as that in Albania. On the other hand, such patterns are also raising concerns about the degree of competition in the Albanian banking sector, which is often criticised for being "overbanked". Therefore, concerns remain high as bank stability may be triggered by excessive bank risk-taking due to further competition, which may shift their focus towards higher profits while ceasing to monitor and to assess risk properly. In another aspect, the GFC did not affect the Albanian economy as strongly as it affected other countries in the SEE. At the same time, banks showed an apparent resilience during this period and similarly they emerged from the GFC in a relatively stable position. However, among other challenging things, problems 
of banks being "too-big-too-fail has also emerged. First, one problem lies in terms of market share, as the 6 largest banks hold nearly $80 \%$ of the market. Second, at a ratio of nearly $16.2 \%$ for the whole market and $22.2 \%$ for the large banks, the Herfindahl-Hirschman index ( $\mathrm{HHI}$ ) suggests that the Albanian banking sector is "moderately concentrated". Similarly, evidences (See Graph 1) show that there is a relatively close relationship between the degree of market power and the extent to which banks are exposed to greater instability, which suggests that competition foreheads bank fragility over time. Therefore, the effect of the regulatory framework on competition and banks' risk-taking incentives and ultimately bank stability make it a particularly interesting environment in which to study the competition-stability nexus.

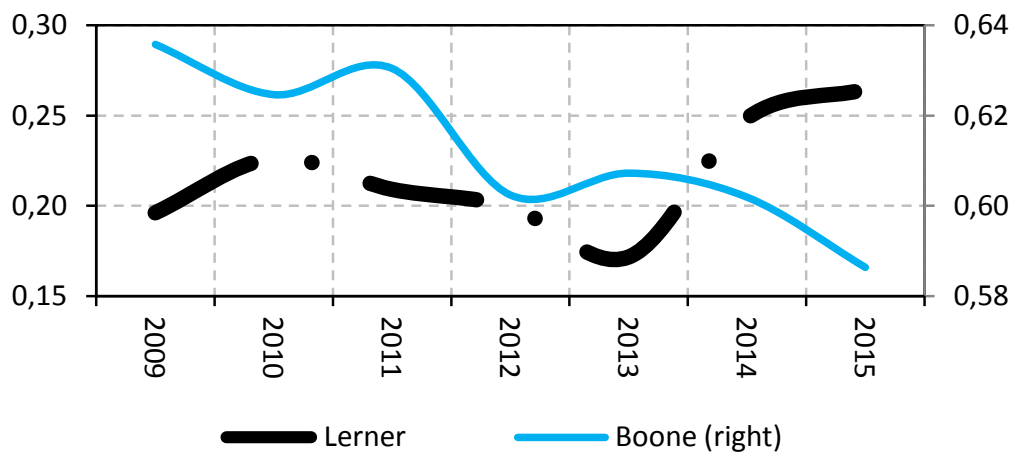

Graph 1. Bank competition and bank stability, 2008 -2015.

Source: Bank of Albania, Author's calculations

Against this background, the existing literature provides a fairly comprehensive review on competition-stability nexus, but of these cases still one question needs to be answered empirically as there is no evidence on the nature of this relationship in the case of a small-opened emerging economy, namely Albania, and in particular after the GFC. The main question, thus, addressed in this paper focuses on how competition affects bank stability after the GFC. The paper makes use of a sample with quarterly data for 16 banks operating in the Albanian financial sector over the period 2008 - 2015. The empirical estimation approach follows a five-step procedure. First, we constructed a new composite individual bank stability indicator. Second, we estimate a competition indicator as suggested by Boone (2008). Then, our specified model is estimated based on the General Method of Moments (GMM) approach. In addition, we deepen our empirical analysis by checking for a possible non-linear relationship between competition and stability in the case of Albanian banking sector. Finally, we use also other alternative structural and non-structural measure of competition, such as the Lerner index and the efficiency-adjusted Lerner index, as well as the profit elasticity and the $\mathrm{HHI}$. 
This paper complements and extends existing literature on this issue in several aspects. First, this paper neither uses real episodes of banking crises or binary approach as a proxy for instability moments nor it uses the Z-score or credit risk as an in-variant measure of the bank's risk-taking behaviour and distance to solvency, to which Fu, Lin and Molyneux (2014) provides some arguments against them as means of bank stability proxies. By contrast, rather than focusing only in one aspect of bank risk exposure e.g. capital, profitability or credit risk, we proceed by using instead a rather more sophisticated proxy for bank stability that includes instead a wide range of information that is based on consolidated balance sheet data with regards to different aspect of bank stability conditions. Then, our proxy for bank stability is estimated through a set of statistical approaches that includes also the use of the principal component analysis approach. Therefore, we strongly believe that our indicator is qualitatively more capable to capture directly the most common factor identifying any possibility of outright bank defaults or/and instability episodes without much loss of information. This approach is advantageous even to the fact that it avoids any pitfalls (e.g. insufficient number of data or false signals) of using the binary approach to crises episodes. At the same time, it solves also for any endogeneity problems between the right hand side and the left hand side variables as mention above. At our best knowledge, no previous study has employed such bank stability indicator as the dependent variable to investigate the competition - stability nexus and we believe this is an important step forward toward a better understanding of the underlying mechanisms. Second, to the best of our knowledge this is also the first study to investigate empirically competition-stability nexus focusing only in the period after the GFC. On the one hand, this highlights the impact of the global turmoil on individual banks' risk exposure. On the other hand, it is another way to test how the financial crisis has changed this relationship. Furthermore, different from previous papers that rely on the use of different forms of Lerner index, $\mathrm{H}$-Statistics or concentrations ratios as a proxy for competition, we improve further the empirical analyses on this field by using instead an alternative competition indicator, such as the one proposed by Boone (2008), which is advantageous even to the fact that it incorporates also the concept of efficiency structure based on bank behaviour. Thirdly, this paper avoids any pitfall as described by Uhde and Heimeshoff (2009) related to data issues and ensure comparability across both dependent and independent variables since it focuses only on a single country. Finally, we do not make use of data from the Bankscope database, but rather we use data taken from the Bank of Albania, which provides the most accurate and reliable dataset on banking sector data.

The empirical findings provide strong evidence supporting the "competitionstability" view that greater degree of competition improves further bank stability conditions. This implies that there is no trade-off between competition and bank stability in the banking sector in Albania. A number of robustness checks confirm also our main findings that support the "completion-stability" view. Results further 
indicate that greater concentration has also a negative impact on bank stability. By contrast, we find no evidence of a non-linear relationship in the competitionstability nexus. Finally, with regards to the control variables, we find that macroeconomic conditions are relatively important for bank stability. Similarly, bank stability is also conditional to improving operation efficiency and capital structure of the banks.

The rest of the paper is structured as follows. Section 2 summarises the literature review. Section 3 presents the methodology with regards to model specification and data. The main results are presented in Section 4 . The material concludes in section 5 .

\section{Literature Review}

The issue of competition-stability nexus remains still ambiguous and unresolved, despite a large body of theoretical and empirical literature (Kasman \& Carvallo, 2014) that explains the reasons and channels through which competition affects bank stability, long before the GFC started. From a theoretical perspective, there are two major streams with utterly opposite views. The competition-fragility view ${ }^{1}$ argues on a (negative) margin effect hypothesis assuming that increasing competition endangers bank stability as it erodes banks' net present value of profits to zero. Therefore, without potential to make future profits (i.e. zero franchise value) banks would relax their investment selection requirements, which in return would give them an incentive to expand or/and take on new riskier policies, including high-risk and high yield investments, in an attempt to maintain the former level of profits. Conversely, the "competition - stability" view ${ }^{2}$ argues on a (positive) margin effect hypothesis. This approach is based on the assumption that banks that have some market power (i.e. positive franchise value) tend to undertake some "credit rationing". Hence, this group of banks might be more prudent in the aspect of risk-taking as they have 'something to lose', which may induce them adverse selection to risky investments (those that jeopardize future profits may not be accepted by banks authorities). Similarly, the considerable market power of only few banks would enhance profits through higher interest rate on loans [Boyd et al. (2003)], which may provide banks with higher "capital buffer" to protect them from adverse external risks and moral hazard (risk shifting) with a negative impact on the stability of the banking system (Beck, et al. 2006, Berger \& Bouwman 2013, Fiordelisi \& Mare 2014). Finally, there are also other studies that assume that $U$-shaped relationship exists. For example, building on the model of Body and De Nicolo (2005), Martinez-Miera and Repullo (2010) show

\footnotetext{
${ }^{1}$ See among others Keeley (1990) Matutes and Vives (2000); Hellmann, Murdock, and Stiglitz (2000); Allen and Gale (2004); Beck, Asli Demirgüç-Kunt, and Levine (2006); Evrensel, (2008); Wagner (2010); and De Haan and Poghosyan, (2012a).

${ }^{2}$ See among others Boot \& Thakor (2000), Bond and De Nicolò (2005), Berger et al. (2009); De Nicolò and Lucchetta (2009); Beck et al. (2006); Berger and Bouwman (2013).
} 
evidences that the probability of bank default first goes down, but then does up after a certain point as bank completion increase. This approach is also supported by findings of Berger et al. (2009), Jeona and Limb (2013), Jiménez, Lopez and Saurina (2013), Liu et al. (2013), and Samantas (2013).

In line with the theoretical views, several authors have tested the competitionstability nexus by focusing on competition indicators that are based on the structure-conduct-paradigm (Beck et al., 2006; Boyd et al., 2006; Behname, 2012; de Haan and Poghosyan, 2012a; de Haan \& Poghosyan, 2012b; Mirzaei et al., 2013; Câpraru \& Andrieş, 2015; Fernández, González \& Suárez, 2016; Pawlowska, 2016) and the relatively market-power hypothesis (Hesse \& Čihák, 2007; Levy Yeyati \& Micco, 2007; Uhde \& Heimeshoff, 2009; Wagner, 2010; Fiordelisi \& Mare, 2014; Pawlowska, 2016), but have found mixed evidence. For instance, Boyd et al. (2006) find that the probability of banks failure increases with market concentration, but as Berger et al. (2009) suggest their conclusions are drawn using some form of concentration indicators, which might be insufficient measures to proxy properly developments within any given market structure. Bushman, Hendricks and Williams (2016) use instead new survey approach of competition and find strong evidence that greater competition surges both individual bank risk and bank's contribution to system-wide risk. However, Leroy and Lucotte (2017) use the Z-score and the Lerner index as in Ahamed and Mallick (2017) to analyse the relationship between competition and bank risk across a large sample of European listed banks over the period 2004-2013. Results suggest that competition encourages bank risk-taking and then increases individual bank fragility. Other papers that confirm the competition-fragility view include Beck et al. (2013), Jiménez et al. (2013), Soedarmono, Machrouh and Tarazi (2013), Fu et al. (2014), Weiß, Neumann and Bostandzic (2014).

By contrast, Beck et al. (2006) and De Nicolò et al. (2009) found that crises are less likely in economies with more concentrated banking systems. Similar, based on a dataset for 38 countries during the period 1980-2003, Schaeck et al., (2009) use the Panzar and Rosse H-Statistics, as an alternative measure of the degree of competitiveness and conclude that more competitive banking systems are less prone to systemic crises and that time to crisis is longer in a competitive environment. However, Jiménez et al. (2013) suggest that standard measure of market concentration do not affect the non-performing loan (NPL) ratio, but found evidence in favour of the franchise value paradigm when using the Lerner index. Other recent empirical papers that validate "competition-stability" view includes Jiménez et al. (2010), Nguyen et al. (2012), Liu and Molyneux (2012), Amidu and Wolfe (2013), Jeona and Limb (2013), Schaeck and Cihak (2014). In addition, there are also other papers that validate both views. For example, Berger et al. (2009) analyse empirically the link between credit risk (NPL ratio), bank stability (Z-score index) and the capital ratio (capital ratio) and several measures of market power (Lerner and $\mathrm{HHI}$ ), using bank level data from Bankscope on 8235 banks in 23 
developed countries. Their results suggest, consistent with the traditional "competition-fragility" view, that banks with a higher degree of market power also have less overall risk exposure. However, the data also provide some support for one element of the competition-stability view - that market power increases loan risk, which may be offset in part by higher capital rations.

The above mention empirical papers produce cross-country evidences. A few studies focusing on a single banking sector includes Zhao, Casu and Ferrari (2010), Fungacova and Weill (2013) and Kasman and Kasman (2015) who yet again provide a mixture of results on the competition-stability nexus. On the contrary, the most relevant work that loosely relates to the research question we address in the case of Albania is done by Dushku $(2016)^{3}$ who investigates the link between competition (measured by Lerner Index) and bank risk-taking (measured by ZScore) for 15 banks operating in Albanian banking system during the period 2004 2014. The author finds a positive link between competition and bank risk and show that the nexus between total (plus foreign) credit risk and competition is nonlinear.

Similar to the theoretical debate, the empirical findings are also challenging. One key challenge that explains the mixed results is related with the inappropriate measure to identify properly bank competition and bank stability (Pawlowska, 2016). For example, Carbó et al. (2009) found that existing indicators of competition (i.e. Lerner index, the H-Statistics) give different conclusions concerning the degree of competition as they tend to measure different things ${ }^{4}$. In terms of the bank risk measure, the available measure is even more limited, while the biggest concern is that most of them do not distinguish which aspect of risks they effectively approximate. It is also obviously that the biggest obstacle and the conclusions of the extant empirical research vary greatly and depend heavily on the data used (Bushman et al., 2016).

This paper complements and extends existing literature on this issue as it make use of superior indicators to measure the state of bank competition and banks stability. Most existing empirical studies investigating this relationship at the microeconomic level focus either on credit risk alone, using some form of credit risk measure such as the NPL ratios, or resort to bank risk measures constructed from balance sheet information, such as the Z-Score. In fact, while the Z-score can be interpreted as the number of standard deviations by which a bank is removed from insolvency, the NPL ratio focuses only on credit risk, but leaves out concerns with regards to liquidity and capital risk or other sort of risks that is linked to the market in which banks operate. Hence, neither of them is a perfect substitute proxy to account for actual bank distress or the probability of default, which are without doubt the most appropriate concepts to define bank risk (Fu et al., 2014; Kick and Prieto, 2015).

\footnotetext{
${ }^{3}$ Note (2006) applies the Panzar-Rosse methodology to measure the competition degree in the Albanian banking system during the period 1999 - 2006. The author finds that Albanian banks operate in monopolistic competition conditions.

${ }^{4}$ See also Bikker, Shaffer \& Spierdijk (2012).
} 
Another concern, as Beck et al. (2013) place in their empirical analysis, is that ZScore and Lerner both include profitability in the numerator and any positive relationship between the two might thus be mechanical rather than economically meaningful. In addition, we neither focused on real episodes of banking crises nor do we use the binary approach as a proxy for instability episodes, which both may either provide insufficient data for estimation purpose or be based on threshold level that are easily criticised or that may produce falls signals of instability moments. By contrast, we extend empirical findings by including instead a more sophisticated proxy for bank stability that is based on a wide range of information that includes different aspect of bank risk exposure rather than focusing only on credit risk or profitability and at the same time benefits through the use of the principal component analysis approach as explained by Shijaku (2016). At our best knowledge, no previous study has employed such bank stability indicator as the dependent variable to investigate the competition-bank stability nexus and we believe this is an important step forward toward a better understanding of the underlying mechanisms. On the one hand, we use a new measure of competition based on the reallocation of profits from inefficient banks to efficient ones as proposed by Boone (2008), which has been used in recent studies ${ }^{5}$.

The existing literature provides a fairly comprehensive review on competitionstability nexus, but of these cases still one question needs to be answered empirically as there is no evidence on the nature of this relationship in the case of a small-opened emerging economy, namely Albania, and in particular after the GFC. The main question, thus, addressed in this paper focuses on how competition affects bank stability after the GFC. The idea is to investigate empirically whether and how, among others things, bank competition is also important for bank stability in the aftermath of the GFC in the case of Albanian banking sector.

\section{Methodology}

\subsection{Dependant Variable}

The empirical literature provides a good description of how one might attempt to build a composite indicator with regards to stability concerns, but obviously this paper follows the Uniform Financial Rating System approach, introduced by the US regulation in 1979, referred to as CAELS rating (Capital adequacy, Asset quality, Earnings, Liquidity and Sensitivity to market risk $^{6}$ as presented in Table 1 . First, using the statistical methods, each indicator included in each of these categorises is

\footnotetext{
5 See also Van Leuvensteijn et al. (2011), Van Leuvensteijn et al. (2013), Kasman and Carvallo (2014), Marques-lbanez et al. (2014), Schaeck and Čihák (2014), Duyguna et al. (2015), Kasman and Kasman (2015).

${ }^{6}$ This approach is also used by International Monetary Fund Compilation Guide 2006 on Financial Soundness Indicators, but others authors e.g. Altman (1986), Sere-Ejembi et al. (2014) and Cleary and Hebb (2016).
} 
normalised into a common scale with mean of zero and standard deviation of one ${ }^{7}$. The formula is given as:

$\mathrm{Z}_{\mathrm{t}}=\left(\frac{\mathrm{X}_{\mathrm{t}}-\overline{\bar{\mu}}}{\bar{\sigma}}\right)$

Where, $X_{t}$ represents the value of indicators $X$ during period $t ; \mu$ is the mean and $\sigma$ is the standard deviation. Second, all the normalised values of the set of correlated indicators used within one category is then converted into a single uncorrelated index by means of the statistical procedure, namely the principal component analysis approach, which is yet again standardised based on the procedure in Equation (1). Then, the estimated sub-index are transformed between the values $[0,1]$ using exponential transformation $\left[1 /\left(1+\exp \left(-Z^{*}\right)\right]\right.$. Finally, our bank stability index (CAELS) is derived as a sum of the estimated exponential transformed subindexes, as follows:

$$
\begin{aligned}
& \mathrm{BSI}_{\mathrm{t}, \mathrm{w}}=\omega_{1} \sum_{\mathrm{i}=1}^{\mathrm{n}} \mathrm{Z}_{\mathrm{t}, \mathrm{C}}^{*}+\omega_{2} \sum_{\mathrm{i}=1}^{\mathrm{n}} \mathrm{Z}_{\mathrm{t}, \mathrm{A}}^{*}+\omega_{3} \sum_{\mathrm{i}=1}^{\mathrm{n}} \mathrm{Z}_{\mathrm{t}, \mathrm{E}}^{*}+\omega_{4} \sum_{\mathrm{i}=1}^{\mathrm{n}} \mathrm{Z}_{\mathrm{t}, \mathrm{L}}^{*}+\omega_{5} \sum_{\mathrm{i}=1}^{\mathrm{n}} \mathrm{Z}_{\mathrm{t}, \mathrm{S}}^{*} \\
& \sum_{*=a, b, c, d, e} \omega^{*}=1
\end{aligned}
$$

Where, $n$ is the number of indicators in each sub-index; ' $C$ ' relates to the capital adequacy; ' $A$ ' represents a proxy to asset quality; ' $E$ ' is a proxy for bank earnings; ' $L$ ' represents a proxy to liquidity risk; and ' $S$ ' is related to the sensitivity of market risk. All indicators used within each category are reported in Table 1 . $Z^{*}$ is the exponential transformed simple average of the normalised values of each indicator included into the sub-index of the individual bank stability index. Then, the estimated index shows a relatively indicator, where an increase in the value of the index at any particular dimension indicates a lower risk in this dimension for the period, compared with other periods.

The advantage of this approach is fourfold. First, CAELS represents a useful "complement" to on-side examination, rather than a substitute for them (Betz et al. 2014), and thereby creates an internal comprehensive monthly-based supervisory "thermometer" instrument that can be used to evaluate bank stability in real time and on an uniform basis and to identify those institutions that requires special supervisory attention and concern with regards to both the present and future banking sector conditions. Second, it builds on the recommendation of ECB (2007). Therefore, we believe it reflects properly the Albanian financial structure as it attaches more weight to banking sector, which is the most prominent agents in the financial markets, while it takes advantages of a broad range of bank level data. Third, the PCA approach highlights the most common factor identifying the patterns in the data without much loss of information, which at the same time solves for any endogeneity problems between the right-hand side and the lefthand side variables as mention above. Four, it does not take the probability form of

\footnotetext{
${ }^{7}$ Normalizing the values avoids introducing aggregation distortions arising from differences in the means of the indicators.
} 
the binary approach, which might expose it either to limitations of insufficient number of episodes or to the vulnerability of the methodology employed to calculate the threshold level. The latter might even provide falls banking distress signals. Rather it consists of a simple approach that is easier to explain and implement. Most importantly it allows analysing the state of the bank as it develops and is also applicable for cross-section comparisons.

\section{Table 1. Indicators used to estimate Bank Stability Index.}

\begin{tabular}{|c|c|c|c|}
\hline Category & Indicator & Notation & $\begin{array}{l}\text { Sub- } \\
\text { Index }\end{array}$ \\
\hline \multirow[t]{8}{*}{ Capital } & Capital Adequacy Ratio & $\mathrm{C}_{1}$ & $\mathrm{Z}_{\mathrm{c}}$ \\
\hline & Core Capital/Total Asset & $\mathrm{C}_{2}$ & \\
\hline & Equity/Total Asset & $\mathrm{C}_{3}$ & \\
\hline & Asset growth & $\mathrm{C}_{4}$ & \\
\hline & Equity Growth & $\mathrm{C}_{5}$ & \\
\hline & Fixed Asset/Regulatory Capital & $\mathrm{C}_{6}$ & \\
\hline & ROE & $\mathrm{C}_{7}$ & \\
\hline & Non-Performing Loan (net)/Regulatory Capital & $\mathrm{C}^{*}{ }_{8}$ & \\
\hline Asset & Non-Performing Loan (net)/Total Loan (net) & $A_{1}^{*}$ & $Z_{A}$ \\
\hline \multirow[t]{5}{*}{ Quality } & Total Loan (net)/Total Asset & $\mathrm{A}_{2}$ & \\
\hline & Growth of Loan Portfolio & $\mathrm{A}_{3}$ & \\
\hline & Credit Loss (Gross)/Total Loan (Gross) & $\mathrm{A}_{4}^{*}$ & \\
\hline & Large Risks (the number of beneficiaries over rate) & $A^{*}{ }_{5}$ & \\
\hline & $\begin{array}{l}\text { Provisions for Loan Loss Coverage/Non-Performing Loan } \\
\text { (gross) }\end{array}$ & $A_{6}^{*}$ & \\
\hline \multirow[t]{8}{*}{ Earnings } & ROA & $\mathrm{E}_{1}$ & $Z_{E}$ \\
\hline & The growth of revenue from interest & $E_{2}$ & \\
\hline & Interest revenue/Total Revenue & $E_{3}$ & \\
\hline & Net Interest Margin & $\mathrm{E}_{4}$ & \\
\hline & Efficiency Ratio & $E_{5}$ & \\
\hline & Interest Revenue (Net)/Operating Revenues (Gross) & $\mathrm{E}_{6}$ & \\
\hline & Dividend/Income (Net) & $\mathrm{E}_{7}$ & \\
\hline & The growth of net interest revenue & $\mathrm{E}_{8}$ & \\
\hline \multirow[t]{3}{*}{ Liquidity } & Net Loan/Average Deposits & $\mathrm{L}_{1}$ & $\mathrm{Z}_{\mathrm{L}}$ \\
\hline & Active Liquid/Total Asset & $\mathrm{L}_{2}$ & \\
\hline & $\begin{array}{l}\text { Asset - Passive with a maturity of three months/Total Asset } \\
\text { that provide profit }\end{array}$ & $L_{3}$ & \\
\hline $\begin{array}{l}\text { Sensitivity } \\
\text { to Market }\end{array}$ & $\begin{array}{l}\text { Asset - Passive sensitive to interest rate with a maturity up to } \\
3 \text { months/Total Asset that Provide Profit }\end{array}$ & $\mathrm{S}^{*}$ & $\mathrm{Z}_{\mathrm{s}}$ \\
\hline \multirow[t]{2}{*}{ Risk } & $\begin{array}{l}\text { Asset - Passive sensitive to interest rate with a maturity up to } \\
12 \text { months/Total Asset that Provide Profit }\end{array}$ & $\mathrm{S}_{2}{ }_{2}$ & \\
\hline & Net Open Position in foreign currency & $\mathrm{S}_{3}$ & \\
\hline
\end{tabular}

* linked to reverse risk order. Source: Author's Calculations 


\subsection{Measuring Competition: The Boone Indicator}

The literature review offers several methods to estimate the degree of competition of a specific sector since this indicator cannot be measured directly. Some of them fall under the so-called the Structural-Conduct-Performance (SCP) approach, which frequently includes indicators referring to numbers of banks, market share, concentration ratio or the Herfindhal-Hirschmann Index (HHI). The other methods are influenced by the New Empirical Industrial Organisation literature, which has been developed primarily from the Lerner (1934) index or price-to-cost margin (PCM) approach and the non-structural models of Iwata (1974), Breshnahan (1982), Panzar and Rose $(1987)^{8}$. In addition to these already popular measures, an alternative measure of competition as proposed by Boone (2008) measures the impact of efficiency on performance in terms of profit. The idea of this profitelasticity index, which is also referred as the Boone indicator $(\beta)$, rests on the assumption that banks with superior efficiency, i.e. banks with lower marginal costs, gain more benefits in terms of profit as a result of market share reallocation from less efficient banks to more efficient ones and this effect becomes stronger in a highly competitive market structure. This means that in a more competitive market banks sacrifice more for being in a cost disadvantage position. Put differently, banks are punished more harshly in terms of profits for cost inefficiency. Therefore, the stronger this effect is the larger in absolute value $\beta$ will be, which is also an indication of greater degree of competitive in that particular market. In the empirical application, the simplest equation to identify the Boone indicator, for bank $i$ at time $t$ is defined as follows:

$\ln \left(\pi_{\mathrm{it}}\right)=\alpha+\sum_{\mathrm{l}=1 \ldots \mathrm{T}}^{\mathrm{L}} \beta \ln \left(\mathrm{MC}_{\mathrm{l}, \mathrm{it}}\right)+\sum_{\mathrm{k}=1}^{\mathrm{K}} \omega \lambda_{\mathrm{k}, \mathrm{it}}+\varepsilon_{\mathrm{it}}$

where $\pi$ and $M C$ denotes the profit and the marginal cost for banks (proxy efficiency) respectively; $\alpha$ is the bank fixed effect; $\lambda$ is a set of control variable associated with the coefficient $\omega$; $\ln$ is the log-linearized transformation of the variables; and $\varepsilon$ is an idiosyncratic shock. The market equilibrium condition is $\mathrm{E}=0$. The $\mathrm{E}$-statistic is $\sum_{\mathrm{l}=1}^{\mathrm{L}} \beta$, which gives the profit elasticity, that is, the percentage change in profits of bank $i$ as a result of a percentage change in the cost of this bank. Theoretically, this indicator is expected to have a negative value, i.e. the increase in costs reduces profit, which can be interpreted as a reduction in the ability of the bank to affect its losses due to an increase in competition. For this reason, we would expect that more efficient banks may choose to translate lower costs either into higher profits or into lower output prices in order to gain market share. As a consequence, using this measure for analysing competition in the

\footnotetext{
${ }^{8}$ The Lerner index has been widely used in recent research including Berger et al. (2009), Cipollini and Fiordelisi (2012); Fu et al. (2014). Dushku (2015) calculates it in the case of Albania by considering the difference between price and marginal cost as a percentage of prices.
} 
banking sector, some researchers ${ }^{9}$ transform the formula of Boone indicator and replace the value of profit with a bank market share, as follows:

$\ln \left(\mathrm{MS}_{\mathrm{it}}\right)=\alpha+\sum_{\mathrm{l}=1 \ldots \mathrm{T}}^{\mathrm{L}} \beta \ln \left(\mathrm{MC}_{\mathrm{l}, \mathrm{it}}\right)+\sum_{\mathrm{k}=1}^{\mathrm{K}} \omega \lambda_{\mathrm{k}, \mathrm{it}}+\varepsilon_{\mathrm{it}}$

Where, $M S$ is the market share of bank $i$ at time $t$. In addition, as in the case of the Lerner index, the Boone indicator is based on the estimation of the marginal costs, which considering the work by Fiordelisi and Mare (2014) and Dushku (2015 and 2016) is estimated through means of a trans-log cost function (TCF), as follows:

$$
\begin{aligned}
\operatorname{lnTC}_{\mathrm{it}}= & \alpha_{0}+\alpha_{1} \ln \mathrm{Q}_{\mathrm{it}}+0.5 \alpha_{2}\left(\ln \mathrm{Q}_{\mathrm{it}}\right)^{2}+\sum_{\mathrm{j}=1}^{3} \beta_{\mathrm{j}} \ln \mathrm{P}_{\mathrm{it}_{\mathrm{j}}}+\sum_{\mathrm{j}=1}^{3} \sum_{\mathrm{k}=1}^{3} \theta_{\mathrm{jk}} \ln _{\mathrm{it}_{\mathrm{j}}} * \\
& \ln \mathrm{itk}+\mathrm{j}=13 \gamma \mathrm{j} \ln \mathrm{it} * \ln \text { Pitj }+\tau 1 \text { Trend }+0.5 \tau 2 \text { Trend } 2+\tau 3 \text { Trend } * \\
& \ln \mathrm{Q}+\text { CRISIS }+\varepsilon_{\mathrm{it}}
\end{aligned}
$$

Where, $T C$ is the total costs of bank $i$ at time $t, Q$ is bank output, $P$ is a vector of input prices, namely labour price $\left(P_{1}\right)$, price of borrowed funds $\left(P_{2}\right)$ and capital price $\left(P_{3}\right)$, Trend is a time trend capturing the dynamics of the cost-function (efficiency) over time, CRISIS is a dummy variable to account for the effect of the GFC, and $\alpha, \beta, \theta, \gamma$ and $\tau$ are coeeficients to be estimated. $\varepsilon_{i t}$ is a two-component error term computed as follows:

$\varepsilon_{\mathrm{it}}=\mu_{\mathrm{it}}+\omega_{\mathrm{it}}$

Where, $\omega_{i t}$ is a two-side error term, and $\mu_{i t}$ is a one-sided disturbance term representing inefficiency. Then, from Equation (6), assuming that inputs' prices are homogeneous, the marginal cost can be derived as follows:

$\mathrm{MC}_{i t}=\frac{\delta \mathrm{TC}_{\mathrm{i}, \mathrm{t}}}{\delta \mathrm{Q}_{\mathrm{i}, \mathrm{t}}}=\frac{\mathrm{TC}_{\mathrm{i}, \mathrm{t}}}{\mathrm{Q}_{\mathrm{i}, \mathrm{t}}}\left[\widehat{\alpha}_{1}+\widehat{\alpha}_{2} \ln \mathrm{Q}_{\mathrm{it}}+\sum_{\mathrm{j}=1}^{3} \hat{\gamma}_{\mathrm{j}} \ln \mathrm{P}_{\mathrm{it}}+\hat{\mathrm{\tau} T r e n d}\right]$

The cost function must be homogenous of degree one in input prices, which imposes some restrictions on the parameter estimates. Linear homogeneity means that the percentage increase in all three input prices raises the value of the cost by the same proportion. This property implies that the value of these three inputs prices included in the cost function represent the total cost. The linear homogeneity in the property of input prices requires the following restrictions on the parameter estimates to hold:

$\sum_{\mathrm{j}=1}^{3} \theta_{\mathrm{j}}=1$

$\sum_{\mathrm{j}=1}^{3} \beta_{\mathrm{j}}=0$

$\sum_{j=1}^{3} \sum_{k=1}^{3} \theta_{j k}=0$

For the research purpose we estimate Boone indicator, using both Equation (4) and Equation (5). However, the former is operationally impossible due to the negative net income generated by some of the banks operating in the Albanian banking

\footnotetext{
${ }^{9}$ Van Leuvensteijn et al. (2011), Tabak, Fazio \& Cajueiro (2012), Van Leuvensteijn et al. (2013).
} 
system in 2008-2010. To overcome this problem the value of the bank profit is replaced by the volume of net interest profit. Then, Equation (4) and Equation (5) are often run by using the Ordinary Least Square (OLS) approach with random effects. The estimated results are reported in Table 2 and $3^{10}$.

Table 2. Results of the estimated TCF model for the banking system in Albania

$\mathrm{TC}=\mathrm{C}(1)+\mathrm{C}(2) * \mathrm{Q}+0.5^{*} \mathrm{C}(3) * \mathrm{Q}^{\wedge} 2+\mathrm{C}(4) * \mathrm{P} 1 * \mathrm{P} 2+\mathrm{C}(5) * \mathrm{P} 1 * \mathrm{P} 3+\mathrm{C}(6) * \mathrm{P} 2 * \mathrm{P} 3+\mathrm{C}(7) * \mathrm{Q} * \mathrm{P} 1+\mathrm{C}(8) * \mathrm{Q} * \mathrm{P} 2$ $+\mathrm{C}(9) * \mathrm{Q} * \mathrm{P} 3+\mathrm{C}(10) * \mathrm{CRISIS}+\mathrm{C}(11) *$ TREND $+0.5 * \mathrm{C}(12) * T_{\text {REND }}^{\wedge} 2+\mathrm{C}(13) *$ TREND*Q

\begin{tabular}{lcccc}
\hline & Coefficient & Std. Error & t-Statistic & Prob. \\
\hline$C(1)$ & -1.841582 & 0.070474 & -26.13149 & 0.0000 \\
$C(2)$ & 0.702095 & 0.013465 & 52.14134 & 0.0000 \\
$C(3)$ & 0.012003 & 0.001404 & 8.548697 & 0.0000 \\
$C(4)$ & 0.125376 & 0.005900 & 21.24969 & 0.0000 \\
$C(5)$ & -0.005697 & 0.001702 & -3.346970 & 0.0009 \\
$C(6)$ & 0.008747 & 0.000853 & 10.24833 & 0.0000 \\
$C(7)$ & -0.016883 & 0.001523 & -11.08201 & 0.0000 \\
$C(8)$ & 0.086373 & 0.000322 & 267.8648 & 0.0000 \\
$C(9)$ & -0.002241 & 0.000210 & -10.66969 & 0.0000 \\
$C(10)$ & 0.007338 & 0.003034 & 2.418254 & 0.0159 \\
$C(11)$ & 0.003709 & 0.001219 & 3.043121 & 0.0024 \\
$C(12)$ & $7.74 E-06$ & $2.57 E-05$ & 0.301182 & 0.7634 \\
$C(13)$ & -0.000390 & $8.56 E-05$ & -4.549645 & 0.0000 \\
\hline R-squared & 0.999681 & Mean dependent var & 8.141240 \\
Adjusted R-squared & 0.999674 & S.D. dependent var & 1.512308 \\
S.E. of regression & 0.027303 & AIC & & -4.341939 \\
SSR & 0.431612 & SIC & & -4.245680 \\
Log likelihood & 1298.214 & HQ & & -4.304445 \\
F-statistic & 151054.4 & DW statistic & & 0.508758 \\
Prob(F-statistic) & 0.000000 & & & \\
\hline
\end{tabular}

Source: Author's Calculations

Table 3. Results of the estimated Boone indicator, for loan market in Albania.

\begin{tabular}{lcllc}
\hline Variable & Coefficient & Std. Error & t-Statistic & Prob. \\
\hline C & 1.529876 & 0.177257 & 8.630823 & 0.0000 \\
MC & -0.224535 & 0.076630 & -2.930128 & 0.0035 \\
CRISIS & 0.017707 & 0.142024 & 0.124679 & 0.9008 \\
\hline R-squared & 0.011254 & Mean dependent var & 1.049670 & \\
Adjusted R-squared & 0.008635 & S.D. dependent var & 1.602471 & \\
S.E. of regression & 1.595538 & AIC & 3.776248 & \\
SSR & 1922.034 & SIC & 3.794576 & \\
Log likelihood & -1428.198 & HQ & 3.783307 & \\
F-statistic & 4.296927 & DW statistic & 0.021330 & \\
Prob(F-statistic) & 0.013945 & & & \\
\hline
\end{tabular}

Source: Author's Calculations

${ }^{10}$ For a detailed analysis see also Shijaku (2017). 


\subsection{The Empirical Approach}

The empirical specified model draws on the extensive review of previous studies related to bank fragility, in particular by Betz et al. (2014) and Black, et al. (2016), but it also departs from them as it deepens further the empirical analyses by including also a proxy of competition instead of market size. Therefore, model is specified as follows:

$\operatorname{CAELS}_{\mathrm{i}, \mathrm{t}}=\alpha+\beta_{\mathrm{i}} *$ Banking $_{\mathrm{i}, \mathrm{t}}^{\prime}+\delta_{\mathrm{i}} *$ Market $_{\mathrm{i}, \mathrm{t}}^{\prime}+\rho_{\mathrm{i}} *$ Macroeconomics $_{\mathrm{j}, \mathrm{t}}^{\prime}+\varepsilon_{\mathrm{i}, \mathrm{t}}$

Where, $C A E L S_{i, t}$ is our stability indicator of bank $i$ at time $t$, with $i=1, \ldots, N$ and $t=$ $1, \ldots, T$, expressed as a function of a set of explanatory variables such as: (1) Banking $g_{i, t}^{\prime}$ is a set of bank-specific explanatory variables, namely operational efficiency and leverage ratio; Market $_{i, t}^{\prime}$ is an industry explanatory variable that proxy by the competition index; Macroeconomics ${ }_{i, t}^{\prime}$ is a set of control variables that account for state of economy, which consists of two variables such as output and primary sovereignty risk. $\alpha$ is a constant term. $b$ is a vector of coefficients to be estimated. $\varepsilon_{i, t}$ is an error terms that is assumed to be identically and independently distributed with mean of 0 and variance $\sigma_{u}^{2} A=\pi r^{2}$.

One potential problem with Equation [10] is the over-identification problems. To correct for this issue, the estimation approach is based on the GMM approach as proposed by Arellano and Bond (1991) and Arellano and Bover (1995) ${ }^{11}$. This approach is also a virtuous to deal with potential endogeneity problems (Anderson \& Hsiao, 1981). The instrument variable is based on the past information of $X_{i, t}^{\prime}$, and to limit the number of instruments, we restrict at 4 the lag range used in generating the instruments as suggested by Roodman (2006). Then, the Haussmann test is used for over-identifying restrictions based on the sample analogy of the moment conditions adapted in the estimation process, thereby as to determine the validity of the instrument variables (i.e. tests of the lack of serial correlation and consistency of instruments variables).

\subsection{Data}

The sample data for this study consists of quarterly data gathered and complied by the Bank of Albania, which is taken from balance sheet and income statement items of 16 banks operating in Albania. The strength of the dataset is its sample coverage and reliability of information. It covers all banks operating in Albania in the last two decade. The sample consists of 960 quarterly data for 16 banks operating in Albania, since 2001 Q01.

The variables used to calculate the competition indicator are as a follow. TC is the sum of personnel expenses, other administrative expenses and other operating expenses. The bank's single output, $Q$, is proxy by bank total assets. $P_{1}$ is calculated

\footnotetext{
${ }^{11}$ Han and Phillips (2010) suggest GMM is constructed to be able to achieve partial identification of the stochastic evolution and to be robust to the remaining un-modelled components.
} 
as the ratio of personnel expenses over total assets. $P_{2}$ is the ratio of other administrative expenses plus other operating expenses over total fixed assets. $P_{3}$ is the ratio of interest expenditure over the sum of total deposits. CRISIS is a dummy variable that takes the value of 1 during the period 2008 Q03 - 2010 Q04, and 0 otherwise. All variables are log-linearized, besides the CRISIS (Table 4). The empirical study focuses on the period 2008 Q02 - 2015 Q03, as the second half of 2008 marks the beginning of pass-through effects of GFC in the Albanian economy ${ }^{12}$. That includes a panel with 448 observations and 28 periods.

\section{Table 4. Data description and Source}

\begin{tabular}{|c|c|c|c|}
\hline Indicator & Description & Source & $\begin{array}{l}\text { Expected } \\
\text { Sign }\end{array}$ \\
\hline CAELS & $\begin{array}{l}\text { Logarithm of the bank stability index as explained in } \\
\text { Section 3.1. }\end{array}$ & $\begin{array}{l}\text { Author's } \\
\text { calculations }\end{array}$ & \\
\hline$G D P$ & Logarithm of the real gross domestic production. & INSTAT & $(+)$ \\
\hline PSRISK & $\begin{array}{l}\text { The spread between domestic } 12 \text { months T-Bills and } \\
\text { the German } 12 \text { months T-Bills. }\end{array}$ & $\begin{array}{l}\text { Bank of Albania, } \\
\text { Bloomberg }\end{array}$ & $(-)$ \\
\hline BOONE & $\begin{array}{l}\text { Logarithm of the estimated competition index } \\
\text { variable as explained in Section 3.2. }\end{array}$ & $\begin{array}{l}\text { Author's } \\
\text { calculation }\end{array}$ & $(+)$ or $(-)$ \\
\hline EFFICIENCY & $\begin{array}{l}\text { Logarithm of the gross expenditure to gross income } \\
\text { ratio }\end{array}$ & Bank of Albania & $(-)$ \\
\hline LEVERAGE & $\begin{array}{l}\text { Logarithm of the equity to asset ratio of individual } \\
\text { banks. }\end{array}$ & Bank of Albania & $(+)$ \\
\hline CRISIS & $\begin{array}{l}\text { Dummy variables that takes the value of } 1 \text { during } \\
\text { the period } 2008 \text { Q3 to } 2010 \text { Q04, and } 0 \text { otherwise. }\end{array}$ & $\begin{array}{l}\text { Author's } \\
\text { calculations }\end{array}$ & $(-)$ \\
\hline$T C$ & $\begin{array}{l}\text { Sum of personnel expenses, other administrative } \\
\text { expenses and other operating expenses. }\end{array}$ & Bank of Albania & \\
\hline$Q$ & Total bank assets & Bank of Albania & \\
\hline$P_{1}$ & Personnel expenses over total assets & Bank of Albania & \\
\hline$P_{2}$ & $\begin{array}{l}\text { Other administrative expenses plus other operating } \\
\text { expenses over total fixed assets }\end{array}$ & Bank of Albania & \\
\hline$P_{3}$ & Interest expenses over total deposits & Bank of Albania & \\
\hline
\end{tabular}

The variables used for empirical analysis are approximated as follows. The bankspecific variables and the stability indicator are estimated individually for each bank. CAELS is transformed into an index, taking as the base year the average performance during the year 2010. EFFICIENCY is the ratio of gross expenditure over gross income. LEVERAGE presents the ratio of equity to asset ratio of individual banks. BOONE is a non-structural competition index variable as explained above. It is transformed also into an index, taking as the base year the average performance during the year 2010. The bank-specific variables and the stability indicator are estimated individually for each bank. The macroeconomic variables

12 The Albanian economy was not affected directly by the GFC, but the spill-over effects through financial and trade linkages were immediately transmitted from 2008 Q04, which at the same time provides a justification why we choose to the empirical estimation from this period. 
are aggregated indicators that represent the state of the economy. GDP represents the real gross domestic production deflating with the Consumer Price Index (CPI). PSRISK represents the spread between domestic 12 months T-Bills and the German 12 months T-Bills. Both interest rates are transformed in real terms by subtracting the respective domestic and German annual inflation rate. All the data are of endperiod values. They are log-transformed, besides the PSRISK and CRISIS. Further, the dataset developed for this paper has several sources. Data on GDP are taken from the Albanian Institute of Statistics. Data on the domestic T-Bills rate are taken from the Ministry of Finance. Data on German 12 months T-Bills rate and German $\mathrm{CPI}$ are taken from Bloomberg. The rest of the data are taken from Bank of Albania.

Finally, prior to the empirical estimation, all the data have been subject to a unit root test procedure on the argument to understand their properties and also to be sure that their order of integration fulfils the criteria for our empirical estimation approach. The latter is a pre-required condition in order to receive consistent and unbiased results. Therefore, the unit root test approach includes the Augmented Dickey-Fuller $(A D F)$ and the Phillips-Peron $(P P)$ Fisher Chi-square tests. The reason is twofold. First, these tests are built on the on the same null hypothesis that panel variable are stationary. Second, they are mostly used for unbalanced panel model, as it is our sample.

\section{Empirical Results}

\subsection{Main Results}

This section reports the main results of our empirical approach. First, as reported in Table 5, the results of the unit root test suggests that EFFICIENCY and LEVERAGE are integrated of order zero I $(0)$ and thus enter the model specification in level. The other variables are found to pose non-stationary properties and are integrated of order one, I(1). Therefore, they enter the model in their first difference, since this approach transforms them into a stationary stance ${ }^{13}$.

Table 5. Panel Unit Root Test.

\begin{tabular}{lllllll}
\hline Variable & ADF - Fisher Chi-square & \multicolumn{4}{c}{ PP - Fisher Chi-square } \\
\cline { 2 - 7 } & Intercept & $\begin{array}{c}\text { Intercept } \\
\text { and Trend }\end{array}$ & None & Intercept & $\begin{array}{l}\text { Intercept } \\
\text { and Trend }\end{array}$ & None \\
\hline$\triangle$ CAELS & 0.0000 & 0.0000 & 0.0000 & 0.0018 & 0.0000 & 0.0000 \\
$\triangle$ GDP & 0.0000 & 0.0000 & 0.0000 & 1.0000 & 0.0000 & 0.0000 \\
$\triangle$ PSRISK & 0.0000 & 0.0000 & 0.0000 & 0.0000 & 1.0000 & 0.0000 \\
$\triangle$ BOONE & 0.0000 & 0.0000 & 0.0000 & 0.0000 & 1.0000 & 0.0000 \\
EFFICIENCY & 0.0000 & 0.0000 & 0.9649 & 0.0000 & 0.0000 & 0.8965 \\
LEVERAGE & 0.0000 & 0.0007 & 0.0001 & 0.0000 & 0.0006 & 0.0010 \\
\hline
\end{tabular}

Note: $\Delta$ is a first difference operator. Probabilities for Fisher tests are computed using an asymptotic Chi-square distribution. All other tests assume asymptotic normality. Source: Author's calculations

${ }^{13}$ These results are robustness also to other unit root test approaches, including the Im, Pesaran and Shin W-stat test and Fisher test. Data can be provided upon request. 
Second, as reported in Table 6, we estimate 2 regressions. In each regression we use the same measure of competition, but to some methodological changes. First, column [1] reports the results of a linear relationship between competition and stability. Second, column [2] presents the results with regards to a possible nonlinearity relationship, which is yet again estimated based on the GMM approach as explained previously.

Table 6. Empirical Results based on GMM approach

\begin{tabular}{|c|c|c|c|c|c|c|c|}
\hline \multirow{2}{*}{$\begin{array}{l}\text { Model } \\
\text { Estimation }\end{array}$} & \multicolumn{7}{|c|}{ Banking System } \\
\hline & 1 & 2 & 3 & 4 & 5 & 6 & 7 \\
\hline$\Delta \mathrm{GDP}$ & $0.7827^{*}$ & $0.9494 * *$ & $0.8169 *$ & $0.5475^{*}$ & $0.7000^{*}$ & $0.7092^{*}$ & $0.9319^{*}$ \\
\hline$\triangle$ PSRISK & $-0.053^{*}$ & $-0.0549 * *$ & $-0.0534^{*}$ & $-0.0301^{*}$ & $-0.0312^{*}$ & $-0.0543^{*}$ & $-0.0279 *$ \\
\hline$\triangle \mathrm{BOONE}$ & $0.171^{*}$ & 0.1996 & & & & & \\
\hline$\triangle \mathrm{BOONE}^{\wedge} 2$ & & -0.0313 & & & & & \\
\hline$\triangle \mathrm{BOONE}^{*}$ & & & $0.0581^{*}$ & & & & \\
\hline LERNER & & & & $-0.2042^{* *}$ & & & \\
\hline LERNER* & & & & & $-0.0312 * * *$ & & \\
\hline PROFITELASTICTYY & & & & & & 0.0304 & \\
\hline $\mathrm{HHI}$ & & & & & & & $-0.9244^{*}$ \\
\hline EFFICIENCY & $-0.304 *$ & $-0.4118^{* * *}$ & $-0.2962 * * *$ & -0.1351 & $-0.3839 *$ & $-0.2946 * *$ & $-0.2252^{* * *}$ \\
\hline LEVERAGE & $0.328 * *$ & $0.5674^{* *}$ & $0.3114^{* * *}$ & $0.2042 * * *$ & $0.4864^{*}$ & 0.0522 & $0.4215^{*}$ \\
\hline Cross-sections & 16 & 16 & 16 & 16 & 16 & 16 & 16 \\
\hline $\begin{array}{l}\text { Instrument } \\
\text { rank }\end{array}$ & 20 & 20 & 20 & 20 & 20 & 20 & 20 \\
\hline $\begin{array}{l}\text { No. of } \\
\text { observations }\end{array}$ & 448 & 448 & 448 & 493 & 434 & 480 & 480 \\
\hline J-statistic & 11.9 & 8.6 & 17.6 & 18.4 & 15.8 & 12.0 & 18.5 \\
\hline $\begin{array}{l}\text { Probability of } \\
\text { J-statistic }\end{array}$ & 0.37 & 0.57 & 0.28 & 0.19 & 0.33 & 0.29 & 0.19 \\
\hline $\operatorname{AR}(1)$ & 0.02 & 0.03 & 0.07 & 0.00 & 0.00 & 0.00 & 0.59 \\
\hline$A R(2)$ & 0.26 & 0.49 & 0.45 & 0.11 & 0.14 & 0.21 & 0.53 \\
\hline
\end{tabular}

Table shows bank-level GMM regressions statistics on the empirical results of the estimations. Haussmann tests (J-Statistics and the Probability of J-Statistics) investigates the validity of the instruments used, and rejection of the null-hypothesis implies that instruments are valid as they are not correlated with the error term. The Arellano and Bond test results also require significant $A R(1)$ serial correlation and lack of $A R(2)$ serial correlation (See also Kasman and Kasman, 2015). The Probability appears in parentheses [ ] below estimated coefficients. Source: Author's Calculations

The model makes uses of 'White Cross-Section' standard errors and covariance (d.f. corrected). At the bottom of the table, we report the specification test results for the GMM estimation. First, $A R(1)$ and $A R(2)$ are the Arellano-Bond tests for first and second order autocorrelation of the residuals. One should reject the null hypothesis of no first order serial correlation and not reject the null hypothesis of no second order serial correlation of the residuals. Second, the Haussmann test of over-identifying restrictions indicates whether the instruments are uncorrelated with the error term. The GMM does not require any distributional assumptions on the error term and it is more efficient that the Two Least Two Square approach as it accounts for heteroskedasticity (Hall, 2005). The results show that in our case the 
requirements are met as suggested by the p-values of the $A R(1)$ and $A R(2)$ tests. In addition, the Haussmann suggests that the instruments used in all the specifications are appropriate. This means that our model is properly specified and that the empirical analyses are robust and consistent with the GMM estimation criterion.

The analyses of estimated coefficients, both external and internal variables, suggest that all the explanatory variables have the expected signs and are statistically significant at conventional level. For example, the coefficient of GDP is positive, suggesting that increases in economic growth have a positive effect on bank stability. This effect is even statistically significant suggesting that the performance of economic activity is quite crucial for bank stability. It is also of great important to understand, however, that from another point of view this result implies that banks place also a relatively consider manner to the economic conditions in which they operate, since an upward movements in economic activity would improve the situation of the banking system through a higher financial intermediation or for low risks related to bank sovereignty risks.

Second, PSRISK has the expected negative effect on bank stability in both regressions ${ }^{14}$. It implies that decreasing sovereignty primary risk, as measured by the spread ratio of domestic and foreign risks, increases bank stability and therefore lower risks are expected to materialise through improving stability conditions of banks. This result complements the findings of Jutasompakorn et al. (2014), but by contrast, the estimated marginal effect is considered to be relatively small, even though it is statistically significant at $10 \%$ level. This suggests that banks consider shocks related to primary sovereignty risk, even though the pass-through is relative small. The reason is fourfold. First, public borrowing has been orientated towards longer term maturities and towards foreign borrowing. This has lowered the pressure on banks and at the same time has provided the market with more foreign liquidity. Second, the government has taken several structural reforms to minimise possible fiscal risks, which includes the pension system reform, energetic sector, etc. Third, banks in Albania operate under a flexible interest rate to which they place a marginal fixed rate. Therefore, any negative shock that leads to an interest rate hike is reflected immediately to their interest barging, making them to some extend hedge to interest rate. Finally, but not the least, different from other countries, banks in Albania have been well-capitalised and have not vulnerable to a shortage of liquidity, despite the recent trends and financial disintermediation.

Similarly, other specific variables associated with patterns at bank level are found to be crucial for bank stability. They have the expected sign and are statistically

\footnotetext{
${ }^{14}$ To assure the authenticity of our results, under the assumption of robustness checks, we also specified the model by using a primary sovereignty indicator that accounts only for the effect of monetary policy shock, proxy in this model as the spread between real term overnight rate and the real EONIA rate. The results were relatively the same. The estimated effect is found to be relatively small, even though statistically significant.
} 
significant at conventional level. For example, the coefficient related to EFFICIENCY is found to have the expected negative sign, supporting the existence of a reserve relationship between operational efficiency and bank stability conditions. It suggests that bank stability would increase proportionally to any upturns in operational efficiency. At the same time, this relationship is also statistically significant at conventional level of $10 \%$, suggesting that it is a fundamental issue in terms of stability concerns. Therefore, bank should be aware that any policy decision-making in an attempt to make banks more attractive, but that might lead to lower productivity would come to a cost in terms of their stability condition. The reason is twofold. First, in order to be competitive and attractive, banks find may find it difficult to pass all the cost to their clients. Second, a few large banks dictate the rule interest rate policy, so the others need to follow them, and that does not allow them to "overcharge". In addition, capital patterns are found to have the expected positive effect on bank stability condition. This effect is statistically significant at $5 \%$ level. This suggests that increasing bank capital is a very important factor and stability condition improves as bank become more capitalised. By contrast, based on size of the coefficient, bank capitalisation is the second most important factor in effecting the stability behaviour of the bank, under the specified model.

At the same time, the results indicate that the coefficient of Boone indicator is positive implying that greater degree of competition improves the state of bank stability conditions, given that higher value of the Boone indicator signifies a higher degree of competition (Table 4). This affect is also found to be statistically significant at conventional level. From an empirical point of view, these findings suggest that changes of marginal cost have more effects on profits and that market share is crucially subject to more competition. Similarly, as competition in the banking sector increases it is likely to boost the franchise value and encourage banks to lower their overall risk exposure, thus confirming the competition-stability view in the case of Albania.

These findings are consistent with the "competition-stability view" of other recent studies (Berger \& Bouwman, 2013; Fiordelisi \& Mare, 2014; Schaeck \& Cihak 2014) that greater bank competition is associated with higher bank stability. However, from the policy point of view one important consideration is that as our measures for competition mainly focus on the lending market, it should be kept in mind that these conclusions are quite subject to loan markets.

Finally, we use also a quadratic term of the measures of competition to capture a possible non-linear relationship between competition and bank stability ${ }^{15}$. Results, as reported in Table 6, column [2], reveal an important consideration that is that we did not find evidence of non-linearity relationship between competition and

\footnotetext{
${ }^{15}$ See also Jimenez et al., (2013), Liu et al. (2013), Fu et al. (2014), Kasman and Kasman (2015).
} 
stability in the case of Albanian banking system, thus rejecting Martinez-Miera and Reputto (2010) model ${ }^{16}$.

\subsection{Robustness Checks}

In an attempt to further enrich our analysis and as a complementary proof we run a number of robustness checks on our main model, as specified in Equation (10), but this time we use five different alternative measures as proxy for bank competition, which are then used also as explanatory variables to get more robust results. For example, column [3] in Table 6 shows the impact of competition, as measured by an alternative Boone indicator that includes also bank capital (Equity) in the estimation of the TCF model, on bank stability [See also Equation A.1 and A.2) in Appendix. The results are relatively similar to those as in the previous sections reconfirming that greater degree of bank competition due to increasing operational efficiency would improve bank stability conditions.

On the other hand, as a robustness check, we also use the estimates of marginal cost from Equation (8) to calculate the Lerner index [LERNER] $]^{17}$ and the efficiencyadjusted Lerner index $\left[L E R N E R^{*}\right]^{18}$, as well as to estimate the profit elasticity $\left[\right.$ PROFITELASTICITY ${ }^{19}$, the results of which are respectively reported in column [4], [5] and [6]. These results show that the LERNER and $L E R N E R^{*}$ are negatively related to CAELS. The impact is also significant. As mention previously, since the Lerner index is inversely proportional to CAELS, it appears that the negative sign for both these competition measures show that increases in the degree of bank pricing power are positively related to individual bank stability in Albanian banking sector. By contrast, the coefficient of PROFITELASTICITY exhibits a positive sign, suggesting that lower elasticity of profit would boost bank stability. These results provide yet again another strong supportive evidence for the competition-stability view, reconfirming as previously that greater degree of bank competition improves bank stability conditions.

Finally, we also examine the impact of bank concentration on the stability of Albanian banks using the $\mathrm{HHI}^{20}$. The results are reported in Table 6, Column (7). The negative coefficient for the $\mathrm{HHI}$ indicator supports a negative link between market

\footnotetext{
${ }^{16}$ We used also a cubic term of the measures of competition to capture a possible non-linear relationship between competition and bank stability, bust still found no supportive evidence. Results are provided upon request.

${ }^{17}$ Following Fiordelisi and Mare (2014) we calculated the Lerner index as $L E R N E R_{i t}=\frac{P_{i, t}-M C_{i, t}}{P_{i, t}}$. The index is a linear straight forward indicator that takes the value between 0 and 1 , with lower value indicating greater degree of competition.

${ }^{18}$ See also Equations A.3 in the Appendix for the approach used to estimate this index.

${ }^{19}$ See also Equations A.4 in the Appendix for the approach used to estimate this index.

${ }^{20}$ It is calculated using bank total asset as inputs (HHIA $=\sum_{\mathrm{i}=1}^{\mathrm{n}} \mathrm{s}_{\mathrm{i}}^{2}$, where $\mathrm{s}$ represents the market share of each bank in total assets in the market). It can range from 0 to 1.0, moving from a huge number of very small firms to a single monopolistic producer. Increases of the index generally indicate a decrease in competition and an increase of market power, and vice versa.
} 
power and bank stability. This suggests that lower bank concentration ratio leads to a decrease in bank insolvency risk, and therefore a higher degree of bank stability. That is that the less concentrated the banking system is the more stable banks are.

By contrast, based on the size of the respectively coefficients, we find that the impact of bank concentration is relatively higher that the extent to which competition effects bank stability. On the one hand, it is very clear that the results remain as those analysed in the previous sections, as in all the regressions, we find that bank market power is negatively related to bank stability, meaning that there is a positive relationship between higher degree of competition and stability. These results support both theories of competition-stability view and concentrationfragility view in the case of Albania showing that banks under less degree of market power are, on average, more stable. On the other hand, the usage of the alternative competitiveness proxy should be treated as a robustness check of the results which further strengths our conclusions in terms of competitions.

\section{Conclusions and Policy Implications}

The developments in the banking market leading to the financial crisis in 2008 heightened new great challenges for bank stability and systemic risk and competition policies. Therefore, this paper fills in the information gap of analysing whether competition improves or reduces banking stability for banks operating in Albanian banking system during the period 2008 - 2015. Although there have been several articles we improve on the existing literature along three crucial dimensions. First, in contrast to other bank-level studies, we use the most direct measure of bank stability available, which is generated from the unique supervisory dataset collected by the Bank of Albania to which we analyse the bank competition-stability nexus. Then, we use a set of alternative proxy of competition indicators, namely the Boone indicator, the Lerner index and the efficient-adjusted Lerner index, profit elasticity and the Herfindahl index. Empirical estimations are based on the General Method of Moments approach. Finally, we further our studies by checking for non-linearity relationship between competition and stability in the case of Albanian banking sector.

The main results provide strong supportive evidence that banks' behaviour towards greater competition has been crucial for boosting bank stability in the aftermath of GFC, thus bolstering the "competition - stability" view. From a policy point of view findings suggest that bank competition and soundness go hand in hand with each other and that higher pricing power during instability periods could simultaneously lead to higher bank stability. Results appear to hold for a wide array of other alternative model specifications, estimation approaches and variable construction. In addition, we find also that during this period bank concentration is inversely correlated to bank stability, thus supporting the view that a more concentrated banking system that easies market power is more vulnerable to systemic instability. For policymakers analysing bank competition these results are crucial not only for 
the stability of the financial sector, but also for the whole economy. Therefore, if one is to boost bank stability during crises period than it is fundamentally essential to increase profit margins (franchise value) as results imply that intense competition in the banking sector is associated lower riskier loan portfolios.

Contrary to the above mentioned results, we provide evidence that do not support a non-linear relationship between competition and stability in the aftermath of GFC in the case of Albania banking system. This is different to the findings of Dushku (2016), thus confirming that the GFC has changed the competition - stability nexus to a linear interaction. Therefore, we suggest that perfect competition is the desirable market structure in order to promote great stability in the banking sector in the case of Albania. In addition, as for other control variables, our results confirm that supervisors and policy-makers should carefully monitor macroeconomic risks since lower economic growth and higher sovereignty risks are associated with greater bank instability. Our results further indicate a negative linkage between operational efficiency and bank stability implying that lower efficiency banks are more destine to bank instability. Finally, our results show that supervisors should be also aware of capital structure of banks as higher capital ratio significantly boosts the state of bank stability conditions.

\section{Acknowledgements}

I would like to express my special thanks and gratitude to my supervisor Professor Franco Fiordelisi for his continues assistance, support and the very helpful comments during my research.

\section{Note}

The views expressed herein are of the author and do not necessarily reflect the views of the Bank of Albania.

\section{References}

Agoraki, M. E. K., Delis, M. D., \& Pasiouras, F. (2011). Regulations, competition and bank risktaking in transition countries. Journal of Financial Stability, 7(1), 38-48. https://doi.org/10.1016/i.jfs.2009.08.002

Ahamed, M. M., \& Mallick, S. (2017). Does regulatory forbearance matter for bank stability? Evidence from creditors' perspective. Journal of Financial Stability, 28, 163-180. https://doi.org/10.1016/i.jfs.2017.01.001

Allen, F., \& Gale, D. (2004). Competition and financial stability. Journal of Money, Credit, and Banking, 36(3), 453-480. https://doi.org/10.1353/mcb.2004.0038

Amidu, M., \& Wolfe, S. (2013). Does bank competition and diversification lead to greater stability? Evidence from emerging markets. Review of Development Finance, 3(3), 152-166. https://doi.org/10.1016/j.rdf.2013.08.002

Amidu, M. (2013). The effects of the structure of banking market and funding strategy on risk and return. International Review of Financial Analysis, 28, 143-155. https://doi.org/10.1016/j.irfa.2013.03.001 
Anderson, T. W., \& Hsiao, C. (1981). Estimation of dynamic models with error components. Journal of the American statistical Association, 76(375), 598-606. https://doi.org/10.1080/01621459.1981.10477691

Arellano, M., \& Bond, S. (1991). Some tests of specification for panel data: Monte Carlo evidence and an application to employment equations. The review of economic studies, 58(2), 277-297. https://doi.org/10.2307/2297968

Arellano, M., \& Bover, O. (1995). Another look at the instrumental variable estimation of error-components models. Journal of econometrics, 68(1), 29-51. https://doi.org/10.1016/0304-4076(94)01642-D

Beck, T., Demirgüç-Kunt, A., \& Levine, R. (2006). Bank concentration, competition, and crises: First results. Journal of Banking \& Finance, 30(5), 1581-1603. https://doi.org/10.1016/j.jbankfin.2005.05.010

Beck, T., De Jonghe, O., \& Schepens, G. (2013). Bank competition and stability: cross-country heterogeneity. Journal of financial Intermediation, 22(2), 218-244. https://doi.org/10.1016/j.jfi.2012.07.001

Behname, M. (2012). The compare of concentration and efficiency in banking industry: evidence from the OPEC countries. Eurasian Journal of Business and Economics, 5(10), 15-24.

Berger, A. N., Klapper, L. F., \& Turk-Ariss, R. (2009). Bank competition and financial stability. Journal of Financial Services Research, 35(2), 99-118. https://doi.org/10.1007/s10693-008-0050-7

Berger, A. N., \& Bouwman, C. H. (2013). How does capital affect bank performance during financial crises?. Journal of Financial Economics, 109(1), 146-176. https://doi.org/10.1016/i.jfineco.2013.02.008

Betz, F., Oprică, S., Peltonen, T. A., \& Sarlin, P. (2014). Predicting distress in European $\begin{array}{llll}\text { banks. Journal of Banking \& 225-241. } & \text { Finance, 45, }\end{array}$ https://doi.org/10.1016/i.jbankfin.2013.11.041

Bikker, J. A., Shaffer, S., \& Spierdijk, L. (2012). Assessing competition with the Panzar-Rosse model: The role of scale, costs, and equilibrium. Review of Economics and Statistics, 94(4), 1025-1044. https://doi.org/10.1162/REST a 00210

Boone, J. (2008). A new way to measure competition. The Economic Journal, 118(531), 12451261. https://doi.org/10.1111/j.1468-0297.2008.02168.x

Boot, A. W., \& Thakor, A. V. (2000). Can relationship banking survive competition?. The journal of Finance, 55(2), 679-713. https://doi.org/10.1111/0022-1082.00223

Smith, M. B. D., De Nicoló, M. G., \& Boyd, J. H. (2003). Crisis in competitive versus monopolistic banking systems (No. 3-188). International Monetary Fund. https://doi.org/10.5089/9781451859584.001

Boyd, J. H., \& De Nicolo, G. (2005). The theory of bank risk taking and competition revisited. The Journal of finance,60(3), 1329-1343. https://doi.org/10.1111/j.1540$\underline{6261.2005 .00763 . x}$

Boyd, J. H., De Nicolò, G., \& Jalal, A. M. (2006). Bank risk-taking and competition revisited: New theory and new evidence.International Monetary Fund, WP/06/297.

Bresnahan, T. F. (1982). The oligopoly solution concept is identified. Economics Letters, 10(12), 87-92. https://doi.org/10.1016/0165-1765(82)90121-5 
Bushman, R. M., Hendricks, B. E., \& Williams, C. D. (2016). Bank Competition: Measurement, Decision-Making, and Risk-Taking. Journal of Accounting Research, 54(3), 777-826. https://doi.org/10.1111/1475-679X.12117

Căpraru, B., \& Andrieş, A. M. (2015). Nexus Between Concentration and Fragility Across EU Banking Systems. Procedia Economics and Finance, 32, 1140-1147. https://doi.org/10.1016/S2212-5671(15)01579-8

Carbó, S., Humphrey, D., Maudos, J., \& Molyneux, P. (2009). Cross-country comparisons of competition and pricing power in European banking. Journal of International Money and Finance, 28(1), 115-134. https://doi.org/10.1016/i.jimonfin.2008.06.005

Cipollini, A., \& Fiordelisi, F. (2012). Economic value, competition and financial distress in the European banking system. Journal of Banking \& Finance, 36(11), 3101-3109. https://doi.org/10.1016/j.jbankfin.2012.07.014

Cleary, S., \& Hebb, G. (2016). An efficient and functional model for predicting bank distress: In and out of sample evidence. Journal of Banking \& Finance, 64, 101-111. https://doi.org/10.1016/j.jbankfin.2015.12.001

Clerides, S., Delis, M. D., \& Kokas, S. (2015). A new data set on competition in national banking markets. Financial Markets, Institutions \& Instruments, 24(2-3), 267-311. https://doi.org/10.1111/fmii.12030

De Haan, J., \& Poghosyan, T. (2012). Bank size, market concentration, and bank earnings volatility in the US. Journal of International Financial Markets, Institutions and Money, 22(1), 35-54. https://doi.org/10.1016/j.intfin.2011.07.002

De Haan, Jakob, and Tigran Poghosyan. (2012b) "Size, market concentration, and bank earnings volatility in the US." Journal of Banking and Finance, 36: 3008-3016. https://doi.org/10.1016/j.jbankfin.2012.07.008

De Nicolò, G., \& Lucchetta, M. (2009). Financial intermediation, competition, and risk: a general equilibrium exposition.IMF Working Paper WP/09/105.

Dushku, E. (2015). Bank Risk-Taking and Competition in the Albanian Banking Sector. Bank of Albania, Economic Review 2015 H1, 4-12.

Dushku, E. (2016). Bank Risk-Taking and Competition in the Albanian Banking Sector. SouthEastern Europe Journal of Economics, 14(2), 187-203.

Duygun, M., Shaban, M., \& Weyman-Jones, T. (2015). Measuring competition using the Boone relative profit difference indicator. Economics Letters, 132, 117-120. https://doi.org/10.1016/j.econlet.2015.04.022

European Central Bank (2007), "Progress Towards a Framework for Financial Stability Assessment", Speech by José Manuel González-Páramo, Member of the Executive Board of the ECB, OECD World Forum on "Statistics, Knowledge and Policy", Istanbul, June 2007.

Evrensel, A. (2008). Banking crisis and financial structure: A survival-time analysis.

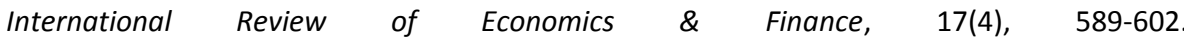
https://doi.org/10.1016/i.iref.2007.07.002

Fernández, A. I., González, F., \& Suárez, N. (2016). Banking stability, competition, and economic volatility. Journal of Financial Stability, 22, 101-120. https://doi.org/10.1016/i.jfs.2016.01.005 
Fiordelisi, F., \& Mare, D. S. (2014). Competition and financial stability in European cooperative banks. Journal of International Money and Finance, 45, 1-16.16. https://doi.org/10.1016/i.jimonfin.2014.02.008

Fu, X. M., Lin, Y. R., \& Molyneux, P. (2014). Bank competition and financial stability in Asia $\begin{array}{llll}\text { Pacific. Journal of Banking \& } \quad \text { 64-77. } & \text { Finance, 38, }\end{array}$ https://doi.org/10.1016/i.jbankfin.2013.09.012

Fungáčová, Z., \& Weill, L. (2009). How market power influences bank failures: Evidence from Russia. Economics of Transition, 21(2): 301-322. https://doi.org/10.1111/ecot.12013

Hall, R., A. (2005). Generalized Methods of Moments. Oxford University Press.

Han, C., \& Phillips, P. C. (2010). GMM estimation for dynamic panels with fixed effects and strong instruments at unity. Econometric theory, 26(01), 119-151. https://doi.org/10.1017/S026646660909063X

Hellmann, T. F., Murdock, K. C., \& Stiglitz, J. E. (2000). Liberalization, moral hazard in banking, and prudential regulation: Are capital requirements enough?. American economic review, 147-165. https://doi.org/10.1257/aer.90.1.147

Iwata, G. (1974). Measurement of conjectural variations in oligopoly. Econometrica: Journal of the Econometric Society, 947-966. https://doi.org/10.2307/1913800

Jeon, J. Q., \& Lim, K. K. (2013). Bank competition and financial stability: A comparison of commercial banks and mutual savings banks in Korea. Pacific-Basin Finance Journal, 25, 253272. https://doi.org/10.1016/i.pacfin.2013.10.003

Jiménez, G., Lopez, J. A., \& Saurina, J. (2013). How does competition affect bank risk$\begin{array}{llll}\text { taking?. Journal of } & \text { Financial } & \text { 185-195. }\end{array}$ https://doi.org/10.1016/i.jfs.2013.02.004

Kasman, A., \& Carvallo, O. (2014). Financial stability, competition and efficiency in Latin American and Caribbean banking. Journal of Applied Economics, 17(2), 301-324. https://doi.org/10.1016/S1514-0326(14)60014-3

Kasman, S., \& Kasman, A. (2015). Bank competition, concentration and financial stability in the Turkish banking industry. Economic Systems, 39(3), 502-517. https://doi.org/10.1016/j.ecosys.2014.12.003

Keeley, M. C. (1990). Deposit insurance, risk, and market power in banking. The American Economic Review, 1183-1200.

Kick, T. K., \& Prieto, E. (2015). Bank risk taking and competition: Evidence from regional banking markets.Review of Finance 19(3): 1185-1222. https://doi.org/10.1093/rof/rfu019

Robinson, J., \& Abba, L. (1934). The Concept Monopoly and the Measurement of Monopoly Power. Review of Economic Studies.1(3): 157-175. https://doi.org/10.2307/2967480

Leroy, A., \& Lucotte, Y. (2017). Is there a competition-stability trade-off in European banking?. Journal of International Financial Markets, Institutions and Money, 46, 199-215. https://doi.org/10.1016/j.intfin.2016.08.009

Yeyati, E. L., \& Micco, A. (2007). Concentration and foreign penetration in Latin American banking sectors: Impact on competition and risk. Journal of Banking \& Finance, 31(6), 16331647. https://doi.org/10.1016/i.jbankfin.2006.11.003

Liu, H., Molyneux, P., \& Nguyen, L. H. (2012). Competition and risk in South East Asian commercial banking. Applied Economics, 44(28), 3627-3644. https://doi.org/10.1080/00036846.2011.579066 
Liu, H., Molyneux, P., \& Wilson, J. O. (2013). Competition and stability in European banking: a regional analysis. The Manchester School, 81(2), 176-201. https://doi.org/10.1111/i.14679957.2011.02285.x

Marques-Ibanez, D., Altunbas, Y., \& Leuvensteijn, M. V. (2014). Competition and Bank Risk The Effect of Securitization and Bank Capital. European Central Bank Working paper series, Nr 1678, May. https://doi.org/10.2139/ssrn.2459063

Martinez-Miera, D., \& Repullo, R. (2010). Does competition reduce the risk of bank failure?. Review of Financial Studies, 23(10), 3638-3664. https://doi.org/10.1093/rfs/hhq057

Matutes, C., \& Vives, X. (2000). Imperfect competition, risk taking, and regulation in banking. European Economic Review, 44(1), 1-34. https://doi.org/10.1016/S0014$\underline{\text { 2921(98)00057-9 }}$

Mirzaei, A., Moore, T., \& Liu, G. (2013). Does market structure matter on banks' profitability and stability? Emerging vs. advanced economies. Journal of Banking \& Finance, 37(8), 29202937. https://doi.org/10.1016/i.jbankfin.2013.04.031

Skully, M., \& Perera, S. (2012). Market power, revenue diversification and bank stability: Evidence from selected South Asian countries. Journal of International Financial Markets, Institutions and Money, 22(4), 897-912. https://doi.org/10.1016/j.intfin.2012.05.008

Note, S. (2007). Competition in the Albanian banking system. Bank of Albania Working Paper, Tirana.

OECD. (2010). Competition, Concentration and Stability in the Banking Sector. Competition Law \& Policy OECD, Policy Roundtables.

Pawlowska, M. (2016). Does the size and market structure of the banking sector have an effect on the financial stability of the European Union?. The Journal of Economic Asymmetries, 14, 112-127. https://doi.org/10.1016/j.jeca.2016.07.009

Roodman, D. (2009). A note on the theme of too many instruments. Oxford Bulletin of Economics and statistics, 71(1), 135-158. https://doi.org/10.1111/j.1468-0084.2008.00542.x

Samantas, I. (2013). Bank competition and financial (in) stability in Europe: A sensitivity analysis.MPRA Paper No. 51621. https://doi.org/10.2139/ssrn.2358999

Schaeck, K., Cihak, M., \& Wolfe, S. (2009). Are competitive banking systems more stable?.Journal of Money, Credit and Banking, 41(4), 711-734. https://doi.org/10.1111/i.1538-4616.2009.00228.x

Schaeck, K., \& Cihák, M. (2014). Competition, efficiency, and stability in banking. Financial Management, 43(1), 215-241. https://doi.org/10.1111/fima.12010

Sere-Ejembi, A., Udom, I. S., Salihu, A., Atoi, N. V., \& Yaaba, B. N. (2014). Developing banking system stability index for Nigeria. CBN Journal of Applied Statistics, 5(1), 49-77.

Shijaku, G. (2016). Banking Stability and its Determinants: A Sensitivity Analysis on Methodological Changes. Bank of Albania, Economic Review 2016, 6H-1, 18-30.

Shijaku, G. (2017). Bank competition in Albania: An analysis through Boone indicator." Bank of Albania, Economic Review 2016 H2, 52-67.

Soedarmono, W., Machrouh, F., \& Tarazi, A. (2013). Bank competition, crisis and risk taking: Evidence from emerging markets in Asia. Journal of International Financial Markets, Institutions and Money, 23, 196-221. https://doi.org/10.1016/i.intfin.2012.09.009 
Tabak, B. M., Fazio, D. M., \& Cajueiro, D. O. (2012). The relationship between banking market competition and risk-taking: Do size and capitalization matter?. Journal of Banking \& Finance, 36(12), 3366-3381. https://doi.org/10.1016/i.jbankfin.2012.07.022

Uhde, A., \& Heimeshoff, U. (2009). Consolidation in banking and financial stability in Europe: Empirical evidence. Journal of Banking \& Finance, 33(7), 1299-1311. https://doi.org/10.1016/i.jbankfin.2009.01.006

Van Leuvensteijn, M., Bikker, J. A., van Rixtel, A. A., \& Sørensen, C. K. (2011). A new approach to measuring competition in the loan markets of the euro area. Applied Economics, 43(23), 3155-3167. https://doi.org/10.1080/00036840903493234

Van Leuvensteijn, M., Sørensen, C. K., Bikker, J. A., \& Van Rixtel, A. A. (2013). Impact of bank competition on the interest rate pass-through in the euro area. Applied Economics, 45(11), 1359-1380. https://doi.org/10.1080/00036846.2011.617697

Wagner, W. (2010). Loan market competition and bank risk-taking. Journal of Financial Services Research, 37(1), 71-81. https://doi.org/10.1007/s10693-009-0073-8

Weiß, G. N., Neumann, S., \& Bostandzic, D. (2014). Systemic risk and bank consolidation: international evidence. Journal of Banking \& Finance, 40, 165-181. https://doi.org/10.1016/j.jbankfin.2013.11.032

Zhao, T., Casu, B., \& Ferrari, A. (2010). The impact of regulatory reforms on cost structure, ownership and competition in Indian banking. Journal of Banking \& Finance, 34(1), 246-254. https://doi.org/10.1016/j.jbankfin.2009.07.022

\section{Appendix}

As a robustness test, we estimate an alternative measure of the marginal cost in the Boone indictor formula ${ }^{21}$ following Leon (2014) and re-specify Equation (3) to include also additional control variable, namely bank capital. The specified model is expressed as follows:

$$
\begin{aligned}
& \operatorname{lnTC} C_{i t}=\alpha_{0}+\alpha_{1} \ln Q_{i t}+0.5 \alpha_{2}\left(\ln Q_{i t}\right)^{2}+\sum_{j=1}^{3} \beta_{j} \ln P_{i t_{j}}+\sum_{j=1}^{3} \sum_{k=1}^{3} \delta_{j k} \ln P_{i t_{j}} \text { * } \\
& \text { InPitk }+j=13 \gamma j \operatorname{lnQit} * \ln \text { Pitji1Trend }+0.5 \tau 2 \text { Trend2 }+\tau 3 \text { Trend } * \\
& \ln Q \omega_{1} \ln E_{i t}+0.5 \omega_{2}\left(\ln E_{i t}\right)^{2}+\omega_{3} \ln E_{i t} * \ln Q+C R I S I S+\varepsilon_{i t}
\end{aligned}
$$

Where, $E_{i t}$ is total equity of bank $\mathrm{i}$ at time $\mathrm{t}$. This model is estimated based on the OLS approach. Then, assuming that inputs' prices are still homogeneous, Equation (6) is re-expressed as follows:

$M C_{i t}=\frac{T C_{i, t}}{Q_{i, t}}\left[\hat{\alpha}_{1}+\hat{\alpha}_{2} \ln Q_{i t}+\sum_{j=1}^{3} \hat{\gamma}_{j} \ln P_{i t_{j}}+\omega_{3} \ln E_{i t}+\tau_{3} \operatorname{Tr} e n d\right]$

Following Clerides, Delis and Kokas (2015) and Kasman and Kasman (2015) we estimated the efficiency-adjusted Lerner index at the bank level, as follows:

$\operatorname{LERNER} R_{i t}^{*}=\frac{\pi_{i, t}+T C_{i, t}-M C_{i, t} * Q_{i, t}}{\pi_{i, t}+T C_{i, t}}$

\footnotetext{
${ }^{21}$ The results are provided upon request.
} 
Where, $\pi_{i, t}$ is the profit of bank $i$ at time $t$, and other are as previously defined. Similar to the conventional Lerner index, the Adjusted Lerner index also ranges from 0 to 1 , with larger values implying greater market power. Then, Clerides et al. (2015) measure the profit elasticity by deriving from the efficiency adjusted Lerner index by solving for $\pi$ in equation A.3. and differentiating with respect to $M C$, as follows:

Profit Elasticity $_{i t}=\frac{Q_{i, t} * M C_{i, t}}{Q_{i, t} * M C_{i, t}-T C_{i, t} *\left(1-\text { Adjusted } L E R N E R_{i t}\right)}$

Hence, the efficiency adjusted Lerner index and the profit elasticity are two closely related concepts. 